\title{
The Use of Stem Cells in the Treatment of Parkinson's Disease
}

\author{
Paul Su, Clare Loane and Marios Politis*
}

Centre for Neuroscience, Department of Medicine, Hammersmith Hospital, Imperial College London, London W12 0NN, UK

* Author to whom correspondence should be addressed; Marios Politis, Hammersmith Hospital, Du Cane Road, London W12 0NN, UK; Tel: +44-020-8383-3751; Fax: +44-020-8383-1783

Email: marios.politis@imperial.ac.uk

Received: 01 June 2011 / Accepted: 28 July 2011 / Published: 04 August 2011

\begin{abstract}
Parkinson's disease (PD) is a degenerative neurological disorder characterized by the cardinal motor features of tremor, bradykinesia and rigidity. It is associated with the extended loss of dopaminergic (DA) neurons in the substantia nigra pars compacta (SNc) resulting in a severe deficiency of DA in the striatum required for motor control. There is currently no cure for PD and the majority of treatments available aim to reverse dopamine deficiency and the relief of the symptoms. Based on promising findings from early trials, the transplantation of stem cells or stem cell derived progenitors has raised the possibility of using cell-based therapy to replace lost cells in the diseased brain. Embryonic stem cells (ESCs) are highly expandable and pluripotent cells that have the ability to differentiate into all cell types of the human body, including nervous system tissues, meaning that they have the potential to offer a lasting treatment for PD and other neurological diseases. However, possible issues with safety and ethics associated with the use of undifferentiated ESCs in humans have meant that alternative sources of transplantable cells has to be considered. Additionally, another approach is the stimulation of brain repair by endogenous stem cells via external manipulation.
\end{abstract}

In this review, recent advances in stem cell research in PD will be discussed, giving an overview of the various strategies including the use of different stem cell populations for cell replacement and the possible modulation of endogenous stem cells that have the potential to provide effective cell-based therapy in future. 
Keywords: Adult stem cells; Dopamine; Embryonic stem cells; Fetal neural stem cells; Induced pluripotent stem cells; Neurogenesis; Parkinson's disease; Transplantation.

\section{Introduction:}

Parkinson's disease (PD) is the second most common neurodegenerative disease of the aging Central Nervous System (CNS) after Alzheimer's dementia. It is a progressive movement disorder associated with motor deficits including tremor, bradykinesia and rigidity, followed by postural instability [1]. The selective degeneration of dopamine (DA) neurons in the substantia nigra pars compacta $(\mathrm{SNc})$ is a characteristic neuropathological hallmark of PD [2], although it should be noted that other non-dopaminergic (non-DA-ergic) systems might also be affected [3]. Clinically, the symptoms of PD do not manifest until up to $70 \%$ of DA-ergic neurons have been lost [4]. This presents a challenge for the treatment of the disease since by the time of diagnosis, the degeneration is largely irreparable and most current pharmacological interventions are only aimed at reversing DA depletion and systemic relief of symptoms. The most widely used form of treatment is levodopa (LDOPA), which produces substantial clinical benefits for some years by providing an exogenous source of DA to the striatum [5]. However, the therapeutic effect of L-DOPA decreases with chronic use and also can result in the manifestation of troubling motor complications such as involuntary movements, so-called, dyskinesias [6].

Cell-based therapy through the application of stem cells has been proposed as future treatments for neurodegenerative disease including PD. Stem cells are defined as immature cells with a capacity of self-renewal and, depending on their origin, can differentiate into specialized cell types or retain the potential to differentiate into any somatic cell, including DA-ergic neurons [7]. The use of cell-based therapy is based on two different strategies; exogenous and endogenous. The former approach involves the introduction of a population of cells (i.e. via transplantation) into the diseased brain in order to replace lost cells and to support the remaining cells (cell replacement). The latter approach, triggers brain repair through enhancing the proliferation, differentiation and migration of host endogenous stem cells (endogenous regeneration). There are a large variety of stem cells including embryonic stem cells (ESC), fetal neural stem cells (fetal NSC), adult stem cells (ASC) and induced pluripotent stem cells (IPSC). Hence, the current research focus is the identification of the optimal cell type that can offer lasting therapeutic efficacy in human PD patients (Figure 1). 
Figure 1: There are two key approaches to stem cell therapy that can be applied in PD: 1) the exogenous cell replacement strategy involves the transplantation of relevant stem cells (i.e. embryonic

stem cells, induced pluripotent stem cells and adult stem cells) or fetal VM tissue that are able to generate therapeutic efficacy (i.e. by differentiating into dopaminergic neurons, or the trigger of DA release etc.); 2) The endogenous regeneration approach involves the stimulation of the host brain stem cells to proliferate, differentiate into dopaminergic neurons, and then to migrate to the relevant regions such as the SNc and the striatal areas.

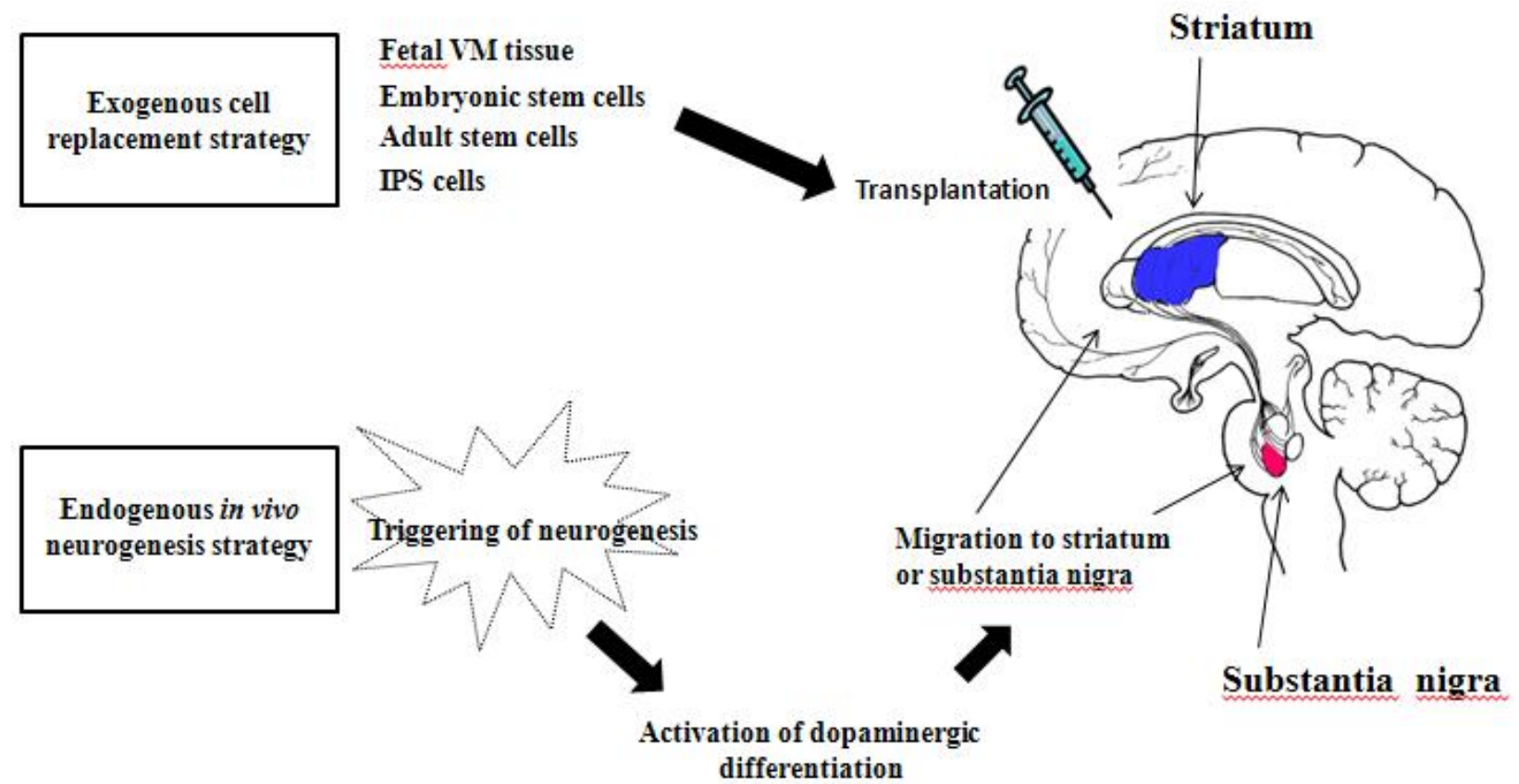

Cell replacement in the treatment of PD is a viable option for the following reasons: 1) PD is a disease that mainly involves the selective destruction of a specific cell population, 2) nigrostriatal DAergic neurons primarily modulate striatal function and provide tonic stimulation of target receptors, and 3) downstream basal ganglia neurons are relatively preserved [8]. Hence, the application of stem cells in PD has the potential for the replacement of lost DA-ergic neurons within the SNc, the reversal of DA deficit in the striatum and the subsequent restoration of brain function [9].

Early transplantation studies have already demonstrated the feasibility of the cell-replacement approach in PD. Moreover, the presence of proliferating stem cells in the adult brain has raised suggestions that the generation of new neurons (neurogenesis) may occur postnatally and thus can potentially be targeted to induce endogenous brain repair. This review aims to discuss the recent findings in the application of stem cells in PD including possible new transplantable sources of cells that may be suitable for cell replacement. Furthermore, advances in the modulation of endogenous stem cells in PD will also be explored. 


\section{Exogenous cell-replacement therapy in PD}

Lasting functional improvement coupled with the absence of adverse side effects in experimental animal models must be established, in order for cell-replacement therapies to move towards clinical application. In PD, evidence for the survival of transplanted cells, integration into the host brain, innervation of the target striatum or SNc, and the presence of functionally mature DA-ergic to replace lost cells must be fully demonstrated. For DA cell-replacement to become a clinically competitive therapy in $\mathrm{PD}$, it must also provide clear advantages over currently available effective treatments for overcoming motor symptoms in PD patients such as deep brain stimulation (DBS) [10].

Early studies in rodent models of PD have assessed the possible therapeutic effect of transplanted ventral mesencephalic (VM) tissue into the lesioned brain. These studies have found that tissue grafts, which are rich in DA-ergic neurons, were able to survive in the host striatum and release DA after integrating into the host neural circuitry. Furthermore, the grafts were able to promote functional recovery of motor deficits $[8,11,12]$. These findings provide proof of principle that neuronal cell replacement has the potential to work in PD and have subsequently led to similar experiments in human patients.

Clinical trials with intrastriatal transplantation of human fetal VM tissue have demonstrated that DA-ergic neurons arising from the grafts were also able to reinnevate the striatum, restore DA release, survive up to 15 years and providing long-lasting symptomatic relief $[13,14]$. However, the results from two double-blinded sham-surgery controlled trials were not as encouraging. In these studies, a significant proportion of graft recipients developed troublesome dyskinesias, while functional benefits were only seen in a limited number of patients $[15,16,17]$.

It is probable that the fetal VM grafts used in these experiments contained not only DA-ergic neurons, but also other cell types such as glial cells, immune cells, fibroblasts and other neurons, with unknown effects on clinical outcome, graft survival and immune reaction. Using in vivo positron emission brain imaging (PET), Politis et al [14] demonstrated the involvement of serotonergic hyperinnervation in the development of dyskinesias in PD patients that have received grafts of VM tissue [14]. Hence, it is unlikely that human VM tissue will ever be used for future routine treatment for PD. Since, stem cells have the potential to provide an unlimited supply of DA-ergic neurons, there is a possibility for them to be utilized for future cell replacement approaches in PD [7].

\section{Stem cells as a source of dopaminergic neurons for cell-replacement}

There are two key properties that define a stem cell: self-renewal, which is the ability to undergo numerous cycles of cell division while maintaining the undifferentiated state; and potency, its differentiation potential (Figure 2a). On this basis, stem cells can be broadly classified as being totipotent, pluripotent or multipotent. Totipotent stem cells can only be isolated from the early developing embryo (i.e. the morula) and can differentiate into any cell type within the body, including extra-embryonic tissue. Similarly to totipotent stem cells, pluripotent stem cells are also capable of differentiating into any cell type so they are able to give rise to cells from any of the three major tissue lineages: the ectoderm, mesoderm and endoderm. Pluripotent stem cells are found in the blastocyst of the embryo, but unlike totipotent cells, these have already begun the differentiation process. Multipotent stem cells are typically lineage restricted meaning they can only differentiate into the 
select cell types from which they are derived and can be isolated from numerous tissue sources within the adult human body. Different types of stem cells (i.e. ESCs, fetal neural stem cells, ASCs and IPSCs) can thus be categorized based on their potency (Figure 2b).

Figure 2: a) Stem cells are defined by their ability to self-renew and to give rise to a variety of different cell types. Stem cells can self-expand for an indefinite period of time, giving rise to identical daughter stem cells. Alternatively, they can commit to a particular cell fate and differentiate into specialised cell types; b) Different stem cells can be mainly categorized as being totipotent, pluripotent or multipotent on the basis of their differentiation capabilities. The level of differentiation capacity in the stem cells depends on the stage in which they are isolated (i.e. early embryo, fetus or adult).

a)

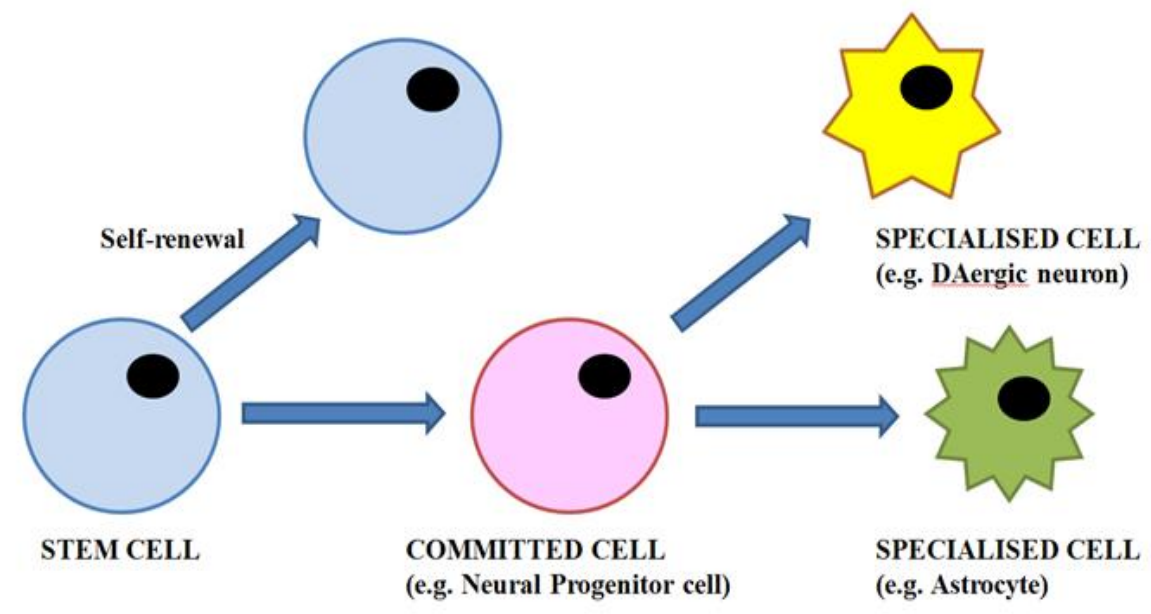

b)

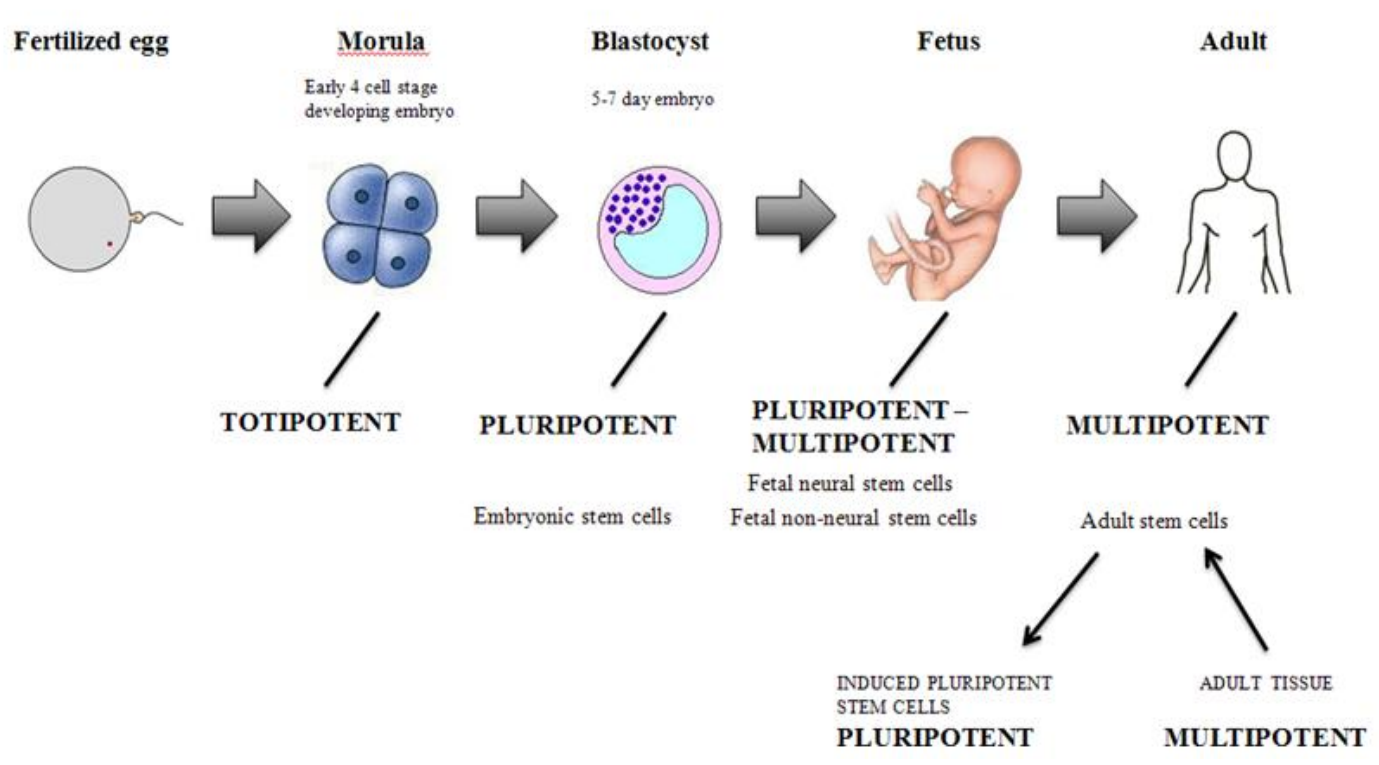


A population of suitable DA-ergic neurons that can be easily obtained, expanded and prepared in vitro is an important requirement for future cell replacement approaches in PD. DA-ergic neurons for grafting could theoretically be generated in large quantities from a range of different stem cells including ESCs, fetal NSCs and ASCs that possess different characteristics. However, ethical issues and problems with tissue availability are major obstacles with the use of embryonic and fetal tissue [18], whereas ASCs are associated with reduced differentiation capacity. Hence, in addition to celltype specific properties that need to be considered, the ability for these cell types to produce functional DA-ergic neurons in vitro and to promote therapeutic efficacy in vivo (i.e. in animal models of PD) also needs to be demonstrated before they can be applied clinically in humans.

\subsection{Embryonic stem cells}

Since ESCs are pluripotent and are highly proliferative, they were deemed to have the greatest potential to be used in the clinical setting in PD as they can give rise to any type of cell in the body including DA-ergic neurons. The fact that they can be engineered in vitro means that ESCs possess many of the necessary characteristics required for an optimal cell source for cell transplantation therapies $[19,20,21]$. However, progress with using ESCs as a viable option for disease therapy has been hindered by the risk of adverse reactions such as tumor formation [7, 22] and immune reactions [23].

Bjorklund et al [22] confirmed the therapeutic potential of ESCs by transplanting undifferentiated mouse ESCs into the striatum of experimentally 6-hydroxydopamine (6-OHDA)-induced parkinsonian rats. The ESCs were able to give rise to DA-ergic neurons that were able to fully integrate into the lesioned brain and mediate hemodynamic changes in the striatum and associated brain circuitry. Consequently, the ESC-derived DA-ergic neurons promoted a gradual and sustained behavioral recovery from motor symptoms. However, $20 \%$ of the rats developed teratoma-like tumors, which is likely due to a high level of unregulated and continuous proliferation of undifferentiated ESCs in the transplants [22]. Hence, the use of pre-differentiated DA-ergic neurons from ESCs has been proposed as a method to reduce the risk of unfavorable tumor formation.

The ability for ESCs to differentiate into DA-ergic neurons in vitro has been demonstrated using mouse ESCs [24, 25, 26], and human ESCs [27, 28, 29]. Additionally, in vitro generated DA cells derived from mouse ESCs was also able to function within the mouse striatum following transplantation and displayed the expected behavioral and electrophysiological properties of midbrain DA-ergic neurons, such as the expression of tyrosine hydroxylase (TH) [30, 31]. Unfortunately, despite promising results using mouse ESCs, grafts with human ESCs showed only partial [32, 33] or no improvement [29] in behavioral deficits following transplantation. Furthermore, the presence of teratomas was still reported suggesting that the use of pre-differentiated DA-ergic neurons was still unable to prevent tumor formation [34]. This is possibly due to a lack of efficiency in the generation of DA-ergic neurons from ESCs, which meant that the graft samples were likely to be contaminated by undifferentiated cells with tumorigenic potential. Moreover, there is evidence to suggest that DA-ergic neurons derived from ESCs also exhibited phenotypic instability and limited survival in vivo [32, 33, 35]. Hence, the possible translation of ESC-based treatment from mouse to humans would require a more efficient protocol for the expansion of uncontaminated and stable populations of DA-ergic neurons. 
Several studies have reported the generation of a large homogenous population of DA-ergic neurons via a novel approach. To reduce contamination by proliferative, undifferentiated cells, human ESCs were first differentiated into neural precursor cells (NPC) that were selectively expanded before giving rise to DA-ergic neurons. The enrichment of NPCs rather than ESCs is a critical step in the purification procedure as it greatly eliminates the presence of the pluripotent and undifferentiated stem cells that are associated with the formation of teratomas. NPCs can be proliferated for an indefinite amount of time without losing their differentiation capability so can be used to produce a large quantity DA-ergic neurons with up to $86 \%$ purity rather than from ESCs directly [36, 37, 38].

To assess the outcome of these purified DA-ergic neurons in vivo, Ravindran et al [39] transplanted NPC-derived DA-ergic neurons into the SNc of a 6-OHDA-lesioned rat model of PD. The transplants elicited a significant reversal of motor deficits and were able to survive for up to one year in the rat brain suggesting a higher stability in NPC-derived DA-ergic neurons. The lack of teratomas reported in this study is also indicative of a lower risk of tumor formation with the use of these cells [39]. The time period concerning the expansion of ESCs and their derivatives may also require careful consideration with regards to tumor formation. Brederlau et al [29] pre-differentiated human ESCs in vitro for 16, 20 or 23 days prior to transplantation into PD rats, where the level of tumor formation was observed. Rats grafted with human ESCs that have been expanded for 16 days developed severe teratomas, whereas most rats grafted with ESCs that have been pre-differentiated for 20 or 23 days remained healthy until the end of the experiment [29].

Taken together, the seemingly lack of stability and survival of pre-differentiated DA-ergic neurons and risk of tumor formation remains a concern with the use of ESCs. Overcoming these problems will largely depend on the removal of undifferentiated proliferating cells and the efficient generation a large homogenous population of DA-ergic neurons prior to transplantation. Whereas mouse ESCs have been shown to promote successful functional recovery from motor deficits in PD animal models, the same level of benefit has not been sufficiently demonstrated using human ESCs. Since it is unlikely that mouse derived cells will be used in the treatment of PD in humans, this is an issue that needs to be addressed. However, due to ethical issues and problems with tissue availability, it remains to be seen whether human ESCs will ever reach clinical application.

\subsection{Fetal neural stem cells}

NSCs have been found to exist in various regions of the fetal and also the adult brain [40, 41]. NSCs that can be harvested from the embryo around embryonic day (E) 14 - E15 in rodents [42, 43, 44] or 13 weeks post-fertilization in humans [45, 46], are multipotent cells that have the ability to regenerate and also to give rise to neurons, oligodendrocytes and astrocytes that represent the three major cell lineages of the CNS [47]. Undifferentiated human fetal NSCs transplanted into the SNc of a MPTP ((1-methyl-4-phenyl-1, 2, 3, 6-tetrahydropyridine)-induced primate model of PD were able to survive, integrate and subsequently reduce some behavioral deficits [46]. However, although it has been shown that fetal NSCs can readily differentiate into DA-ergic neurons, a major issue of using these cells is the low yield (1-5\%) of generated DA-ergic neurons [46, 48, 49, 50]. Hence, it seems that when compared to ESCs, fetal NSCs are not advantageous when it comes to production of DAergic neurons due to a much-reduced proliferative potential. Nevertheless, a reduced proliferative capacity means that fetal NSCs are associated with a lower risk of tumor formation [51]. 
Furthermore, rat fetal NSCs have also been shown to demonstrate high migratory ability and affinity towards damaged brain regions, which is significant when considering future transplantation in humans, as it is essential that transplanted cells fully reach the target regions [44].

There are various studies that have explored ways to increase DA-ergic differentiation of rat fetal NSCs. The first in vitro assessments of mouse fetal NSCs has revealed that NSC proliferation can be induced using fibroblast growth factor-2 (FGF-2) [52], and epidermal growth factor (EGF) [53], while retaining the ability to differentiate into CNS progeny. This has led to successful transplantation studies in PD rat models as demonstrated by a greater yield of rat fetal NSC-derived DA-ergic neurons and significant recovery from motor deficits $[54,55]$. Other substances such as cytokines (i.e. interleukin-1 $\beta$ and interleukin-11) [46, 56], and glial neurotrophic factors (GDNF) (i.e. neurturin; NTN) [57] may also be able to modulate and increase NSC differentiation towards a DA-ergic phenotype. Additional strategies to improve the yield of generated DA-ergic neurons include the overexpression of key DA-ergic cell-fate determining transcription factors [58]. Kim et al [59] overexpressed Nurr1 in rat fetal NSCs that was able to promote DA-ergic-specific properties of derived neurons including DA release, but the generated DA-ergic neurons lacked maturity and were unable to induce any functional benefits when transplanted into parkinsonian rats [59]. Adopting a similar approach, O'Keeffe et al [43] overexpressed PITx3 in rat fetal NSCs that showed improvement in stability of NSC-derived DA-ergic neurons and recovery from motor deficits in PD rats [43]. The co-expression of a combination of these transcription factors is likely to enhance differentiation of fetal NSCs and increase stability [60].

Overall, fetal NSCs possess some attractive characteristics that make it ideal for cell-based therapy in $\mathrm{PD}$, although its restrictive proliferative capacity resulting in a low yield of generated DA-ergic neurons may limit their preclinical and clinical usefulness. Although different approaches to optimize DA-ergic differentiation has been tested with relative success using rat fetal NSCs by increasing quantities of generated DA-ergic neurons, these have not been fully tested in human fetal NSCs. There is also a lack of evidence that human fetal NSCs can be grafted with the level of functional integration and phenotypic stability that is the basic requirement for clinical effectiveness.

\subsection{Adult stem cells}

Multipotent ASCs as an alternative source of DA-ergic neurons has drawn a lot of research interest due to their potential for autologous transplantation therapies in which cells can be harvested and used within the same patient. The use of ASCs is also particularly attractive as it can overcome the ethical issues and with a relative low risk of problems with tissue rejection (i.e. if patient specific stem cells are used), although, there are restrictions due to its more limited ability to differentiate. ASCs can be isolated from a large variety of tissues such as the CNS [40, 41, 61], bone marrow [62], dental pulp cavity [63], olfactory mucosa [64] and umbilical cord blood [65].

Adult NSCs are representative of cells in the postnatal brain that retain the capacity to renew themselves and to differentiate into the major cell types of the CNS so are seemingly a logical candidate for autologous transplantation approaches. Similarly to fetal NSCs, adult NSCs isolated from the postnatal brain can be expanded and driven to DA-ergic differentiation via the overexpression of Nurr1, and providing some functional benefits in vivo [66]. The possible therapeutic efficacy of adult NSCs has also been demonstrated in humans. In a partial study involving a neurosurgical 
procedure, cortical tissue was obtained from a human PD patient, where the adult NSCs were expanded and differentiated in vitro, before being transplanted back into the same patient. The autologous transplant was able to elicit lasting motor improvement and restoration of DA-ergic function based on a 55\% increase in Fluorine-18-DOPA $\left({ }^{18} \mathrm{~F}\right.$-DOPA) PET uptake [67]. However, notwithstanding these encouraging results, the extraction of adult NSCs especially from an already damaged PD brain is invasive and can be deemed too unsafe for this approach to be adopted into a routine PD therapy.

Mesenchymal stem cells (MSCs) are a promising alternative source of autologous ASCs and unlike NSCs, are highly accessible and can be harvested from the bone marrow, as well as other tissues including cord- and peripheral blood. There is evidence that the application of MSCs can be effective in a PD therapeutic strategy. Intrastriatal grafting of MSCs into adult intact rats resulted in a significant elevation of $\mathrm{TH}$ expression and DA levels in the striatum [68]. Other experiments have reported functional recovery in PD rodent models following transplantation of MSCs that are indicative of a neuroprotective role in vivo [69. 70, 71, 72]. For example, transplantation of undifferentiated human MSCs was able to protect against 6-OHDA-mediated neurotoxicity in rats [71]. The observed neuroprotective effect in vivo was possibly due to an immune-modulatory role by the grafted MSCs. Chao et al [72] reported that MSCs were able to inhibit the expression of mannose binding lectins (MBL) that is important for microglial activation and amplification of inflammatory processes. Furthermore, transplanted MSCs were also found to repair MPTP-mediated damage to the blood brain barrier (BBB), thus preventing the recruitment and entry of peripheral immune cells into the brain parenchyma [72].

Interestingly, despite being lineage-restricted, multipotent MSCs have been reported to exhibit neuronal features such as the expression of neural markers $[73,74]$, and can be induced to differentiate into DA-ergic neurons. Trzaska et al [75] generated electrophysiological functioning DA-ergic neurons from human MSCs using a cocktail of sonic hedgehog (shh), basic FGF and FGF8 [75]. PD patient-derived MSCs are also functionally indistinguishable from normal individual-derived MSCs in phenotype, morphology and multidifferentiation capacity [76]. This is important if the potential of autologous transplantation approaches using MSCs is to be realized.

Encouraging experimental findings from animal models have led to a recent open-labeled study using autologous PD patient-derived MSCs. 3 out of 7 PD patients that have received autologous MSC grafts have shown steady motor improvements and presented no adverse effects posttransplantation [77]. While this seems positive, this study cannot rule out the placebo effect being responsible for the marginal improvements in motor score. Furthermore, the low study size, the uncontrolled nature of the trail and the fact that functional benefits were not seen in all patients meant that this study couldn't reliably demonstrate the effectiveness of treatment using autologous MSCs [77].

Retinal pigment epithelial (RPE) cells are melanin-secreting cells that are present in the inner layer of the neural retina have also received special attention for cell-based therapy in PD. RPE cells play a key role in maintaining the normal function of the retina and are capable of producing L-DOPA endogenously as an intermediate product of melanin through the catalyzation of tyrosine [78]. It was hypothesized that the transplantation of RPE cells into the nigrostriatal pathway would permit the conversion of RPE-derived L-DOPA to DA, thus potentially providing a direct source of DA to the dennervated PD brain. Studies in rat 6-OHDA-lesioned rats have reported that transplantation of 
human RPE cells were able to ameliorate functional deficits [79]. Moreover, human RPE cells were able to survive in the striatum, synthesize DA and promote neuroprotection via the release of brain derived neurotrophic factor (BDNF) and glial derived neurotrophic factor (GDNF) [80]. Unfortunately, these promising results from animal models could not be translated to humans based on a recent double-blinded sham surgery in PD patients. In this study utilizing 71 patients (35 receiving RPE transplants; 36 receiving sham surgery), there was no significant difference in motor score between subject groups. Hence, transplantation of human RPE cells provided no antiparkinsonian benefits compared with sham surgery [81].

\subsection{Induced pluripotent stem cells}

The recently acquired ability to reprogram human adult somatic cells to induced pluripotent stem cells (IPSCs) has raised the prospect of generating an unlimited source of patient-specific cells for cell replacement therapy. Through the expression of exogenous transcription factors, the IPSC technique makes it possible to increase pluripotency in cells that are normally non-pluripotent (i.e. terminally differentiated cells), so they share similar properties to ESCs in their differentiation capabilities (for a review see [82]). Unlike ESCs, since IPSCs can be generated from somatic cells from each individual including patients, the use of IPSCs can overcome the ethical issues and problems with immune rejection and tissue availability. The induction of pluripotency in patient-derived somatic cells can also provide the opportunity to produce an unlimited supply of patient-specific DA-ergic neurons for autologous transplantation.

Takahashi et al [83] first demonstrated the induction of pluripotency using mouse fibroblasts by introducing four genetic factors: Oct4, Sox2, c-Myc and Klf4 [83], where the results have since been successfully translated from mouse to humans $[84,85]$. Based on their morphology, growth, surface antigens, gene expression, and ability to differentiate into cells of the three germ layers (ectoderm, mesoderm and endoderm), the generated IPSCs were almost indistinguishable to ESCs [85].

There have been numerous studies that have assessed the therapeutic effect of IPSCs in vivo [86, 87, 88, 89]. Fibroblast IPSCs can be differentiated in DA-ergic neurons that were able to functionally integrate into the host brain and improve symptoms in parkinsonian rats [86]. PD patient-derived IPSCs were also able to give rise to fully functional DA-ergic neurons [90,91] with the same clinically relevant striatal re-innervation as normal individual-derived IPSCs [88]. These results highlight the potential therapeutic efficacy of IPSCs in PD and provide evidence of survival and functional effects of patient-specific IPSCs in vivo.

Although IPSCs can overcome the ethical problems, due to their similarities to ESCs, they are at least expected to face the same challenges, plus additional challenges due to the way they are generated and if patient-derived IPSCs are used. For example, while transplanted grafts can be subjected to the occurrence of lewy body pathology in the PD brain (host to graft disease propagation) $[92,93]$, it is possible that patient-derived IPSCs may carry mutations that make them even more susceptible to developing PD-like features than other stem cell sources. It also remains to be determined whether the in vivo functionality and phenotype of IPSC-derived DA-ergic neurons (especially those derived from PD patients) are as stable as those derived from ESCs. It is still relatively unknown as to the long-term outcome of IPSC grafts in humans. As with ESCs, the risk of tumor formation remains an issue. The common use of viral vectors to generate IPSCs could increase 
the risk of teratomas due to reactivation of the oncogene c-Myc [94], while the reprogramming agents can also influence the tumor repressor protein p53 [95]

Nevertheless, with the rapid advancement of IPSC technology, we cannot rule out the possibility that some of these obstacles may be overcome in the future. Recently, it has been reported that fibroblasts can be directly reprogrammed into neurons using the genetic factors: Ast11, Brn2, Myt11, thus bypassing the need for the initial generation of undifferentiated cells [96]. This can potentially reduce the risk of tumors, although further investigation would have to be conducted to verify whether this can be applied clinically.

\section{Alternative approaches to stem cell-based therapy}

\subsection{Artificial nigralstriatal re-innervation following orthotopic transplantation}

An alternative approach to ectopic transplantation into the striatum is the orthotopic transplantation of DA-ergic neurons; a strategy that is based on the assumption that placing nigral neurons in their natural (i.e. the $\mathrm{SNc}$ ) would provide a more integrated system both anatomically and functionally [97]. However, this would require the effective reconstruction of the nigralstriatal pathway to enable the grafted neurons to integrate into the basal ganglial circuitries. Recently, Gaillard et al [98] confirmed the feasibility of intranigral transplantation where fetal VM tissue injected into the mouse lesioned $\mathrm{SNc}$ gave rise to DA-ergic neurons that were able to integrate and develop neuronal projections towards the striatum, increase DA levels and restored normal behavior [98].

It is possible to produce an artificial nerve pathway to direct nigralstriatal reinnervation between graft and target striatum; a process known as bridging by using a combination of substances and growth factors such as kainic acid [99] and GDNF [100]. The identification of a suitable material that is safe and biodegradable is a challenge with using bridging technology. Most currently used molecular scaffolds are largely primitive structures based on a limited number of components, which do not closely represent the complex natural extracellular matrix (ECM) [101]. Discher et al [102] reported the influence of cellular substrate properties such as stiffness on cell differentiation processes [102]. Therefore, if artificial re-innervation of the nigrostriatal pathway is to be achieved in humans, the establishment of a bridging material that can mimic the characteristics of the natural ECM to control proliferation, differentiation and cell migration is essential. Nevertheless, progress regarding this is largely underway [103, 104].

\subsection{The induction of endogenous stem cell neurogenesis}

Until the mid-1990s, it was generally accepted that the CNS had a limited capacity for self-repair. However, the presence of proliferating NSCs in various regions of the adult brain including the dentate gyrus (DG) [40], subventricular zone (SVZ) [105, 106], SNc [107] and cortex [108] suggest that neurogenesis might occur postnatally. A postmortem study has reported the generation of new neurons from dividing progenitor cells residing in the adult hippocampus [109]. Hence, endogenous neurogenesis can potentially be exploited by cell-based therapy in PD through the induction of endogenous NSCs to induce brain repair.

Neurogenesis is likely to be strongly influenced by the local microenvironment (i.e. by local cell extrinsic cues) as it was reported NSC-derived SVZ precursor cells can only differentiate into DA- 
ergic neurons within the bulbus olfactorious, whereas DA-ergic neurogenesis is generally inhibited in other brain regions [110]. However SVZ precursors may also be responsive to external modulation, as demonstrated by intraventricular treatment using EGF or FGF2, which was able to induce migration and proliferation of SVZ cells to form new neurons [111, 112]. Brain injury has also been found to enhance neurogenesis in the striatum [113] and the SN [107].

Successful endogenous stem cell-based therapy has to result in efficient induction of NSC proliferation, DA-ergic differentiation and survival of newly generated cells. However, the optimal approach for endogenous stem cell-based therapy is unknown, although various strategies can be adopted. To restore DA levels to the depleted striatum, it may be possible to generate DA-ergic neurons through recruitment of endogenous SVZ NSCs, or stimulation of the resident cells within the striatum.

Cell recruitment of endogenous NSCs into the striatum has already been demonstrated in PD animal models, where growth factors such as platelet-derived growth factor (PDGF) [114], brain-derived neurotrophic factor (BDNF) [115] and transforming growth factor-alpha (TNF $\alpha)$ [111] was able to recruit SVZ progenitors into the striatum in PD rats. This has led to improvement motor deficits, although it cannot be fully elucidated whether DA-ergic differentiation of recruited SVZ cells has occurred [111, 116]. Alternatively, endogenous NSCs can be recruited to the SNc. Although this would also require a suitable bridging agent to direct neuronal outgrowths to the target striatum, this approach offers potential for the reconstruction of the nigralstriatal pathway.

\section{Conclusions}

Stem cell-based therapies aim to provide a long-lasting symptomatic relief for PD patients. There are two main strategies to the use of stem cells in PD; firstly, the exogenous approach of cellreplacement involves the transplantation of stem cells that can generate dopaminergic neurons in order to replace the lost cells and subsequent reversal of striatal DA depletion; and secondly, the endogenous approach of in vivo neurogenesis involves the triggering of brain repair through the induction of endogenous stem cells to proliferate, differentiate and migrate to the damaged brain areas.

Early studies have provided proof of principle that transplantation of fetal VM-derived DAergic neurons can improve symptoms in PD patients. However, due to problems with tissue availability, ethical issues and serious side effects, it is unlikely that VM tissue would ever be used as routine treatment in PD. Stem cells have the potential to generate an unlimited supply of functional, mature DAergic neurons that are able to survive, integrate into the host circuitry and subsequently promote functional recovery in PD patients. As there are a large variety of different stem cells, much of the current research focus is aimed at identifying the ideal type that can fulfill this role (Table 1).

Despite some promising results from in vitro and animal studies, the translation of these findings from animals to humans have generally led to disappointment from clinical human trials. Successful cell-replacement therapy in PD has to meet at least the following targets: 1) Long term integration and survival in host tissue (i.e. the striatum) following transplantation; 2) Differentiation into functional DAergic neurons that exhibit the correct molecular and morphological characteristics expected of midbrain mature DAergic neurons; 3) Release of DA in a regulated manner and subsequent restoration of DA depletion; 4) long-term efficacy in reversing behavioral deficits in PD patients and 5) Minimum side effects including tumor formation and dyskinesias. It is crucial that all these targets are fulfilled 
in in vivo assessments before attempts to translate these findings from animals to humans are performed. Until this is consistently demonstrated experimentally, human clinical trials largely remain a premature step.

Table 1: A brief summary of the stem cell types that have the potential to generate suitable dopaminergic neurons and their advantages and disadvantages

\begin{tabular}{|l|l|l|l|}
\hline Type of Stem cell & Source & Advantages & Disadvantages \\
\hline Embryonic stem cells & $\begin{array}{l}\text { Embryo } \\
\text { (Blastocyst) }\end{array}$ & Pluripotent & $\begin{array}{l}\text { Ethical problems } \\
\text { Safety concerns } \\
\text { Tissue availability } \\
\text { Unpredictable differentiation }\end{array}$ \\
\hline Fetal neural stem cells & Fetus & $\begin{array}{l}\text { Multipotent (for neural cell } \\
\text { types) }\end{array}$ & $\begin{array}{l}\text { Ethical problems } \\
\text { Safety concerns } \\
\text { Tissue availability } \\
\text { Difficulty in directing relevant differentiation }\end{array}$ \\
\hline Adult neural stem cells & $\begin{array}{l}\text { Adult tissue } \\
\text { (CNS) }\end{array}$ & $\begin{array}{l}\text { Multipotent (for neural cell } \\
\text { types) } \\
\text { Autologous-based therapy } \\
\text { Ethically favourable }\end{array}$ & $\begin{array}{l}\text { Safety concerns } \\
\text { Difficult to extract }\end{array}$ \\
\hline Adult non-neural stem cells & $\begin{array}{l}\text { Adult tissue } \\
\text { (various) }\end{array}$ & $\begin{array}{l}\text { Autologous-based therapy } \\
\text { Ethically favourable } \\
\text { Tissue availability }\end{array}$ & $\begin{array}{l}\text { Safety concerns } \\
\text { Lineage restricted }\end{array}$ \\
\hline Pluripotent stem cells & $\begin{array}{l}\text { Adult tissue } \\
\text { (various) }\end{array}$ & $\begin{array}{l}\text { Pluripotent } \\
\text { Autologous-based therapy } \\
\text { Ethically favourable } \\
\text { Tissue availability }\end{array}$ & Safety concerns \\
\hline
\end{tabular}

\section{Acknowledgements}

Our own work was supported by the Medical Research Council UK and the Michael J. Fox Foundation for Parkinson's Research USA.

\section{References}

1. Fahn S, Elton RL. Members of the UPDRS Development Committee. Unified Parkinson's disease Rating Scale. In: Fahn S, Marsden CD, Jenner P, Teychenne P. Recent developments in Parkinson's disease. Macmillan Healthcare Information 1987; 2: 153-164.

2. Fearnley JM, Lees AJ. Aging and Parkinson's disease: substantia nigra regional selectivity. Brain 1991; 114: 2283-301.

3. Braak H, Rub U, Del Tredici K. Cognitive decline correlates with neuropathological stage in Parkinson's disease. J Neurol Sci 2006; 248 (1-2): 255-258.

4. Dunnett SB, Björklund A, Lindvall O. Cell therapy in Parkinson's disease - stop or go? Nat Rev Neurosci 2001; 2 (5): 365-369.

5. Fahn S. Description of Parkinson's disease as a clinical syndrome. Ann N Y Acad Sci 2003; 991: $1-14$.

6. Marsden CD, Parkes JD. On-off effects in patients with Parkinson's disease on chronic levodopa therapy. Lancet 1973; 1: 292-296.

7. Lindvall O, Kokaia Z, Martinez-Serrano A. Stem cell therapy for human neurodegenerative disorders-how to make it work. Nat Med 2004; Neurodegeneration: 42-50. 
8. Palmer MR, Granholm AC, van Horne CG, Giardina KE, Freund RK, Moorhead JW, et al. Intranigral transplantation of solid tissue ventral mesencephalon or striatal grafts induces behavioral recovery in 6- OHDA-lesioned rats. Brain Res 2001; 890: 86-99.

9. Lindvall O, Kolaia Z. Stem cell therapy for human brain disorders. Kidney International 2005; 68: 1937-1939.

10. Lindvall O, Kokaia Z. Prospects of stem cell therapy or replacing dopamine neurons in Parkinson's disease. Trends Phar Sci 2009; 30 (5): 260-267.

11. Brundin P, Isacson O, Gage FH, Prochiantz A, Bjorklund A. The rotating 6-hydroxydopaminelesioned mouse as a model for assessing functional effects of neuronal grafting. Brain Res 1986; 366 (1-2): 346-349.

12. Nikkhah G, Cunningham MG, Cenci MA, McKay RD, Bjorklund A. Dopaminergic microtransplants into the substantia of neonatal rats with bilateral 6-OHDA lesions. I. Evidence for anatomical reconstruction of the nigrostriatal pathway. J Neurol Sci 1995; (5 pt. 1): 3548-61

13. Piccini P, Brooks DJ, Bjorklund A Gunn RN, Grasby PM, Rimoldi O, et al. Dopamine release from nigral transplantsvisualised in vivo in a Parkinson's patient. Nat Neurosci 1999; 2 (12): 1137-1140.

14. Politis M, Wu K, Loane C, Quinn NP, Brooks DJ, Rehncrona S, Bjorklund A, Lindvall O, Piccini P. Serotonergic neurons mediate dyskinesia side effects in Parkinson's patients with neural transplants. Sci Transl Med 2010; 2 (38): 38-46.

15. Freed CR, Greene PE, Breeze RE, Tsai WY, DuMouchel W, Kao R, et al. Transplantation of embryonic dopamine neurons for severe Parkinson's disease. N Engl J Med 2001; 344: 710-719

16. Olanow CW, Goetz CG, Kordower JH, Stoessl AJ, Sossi V, Brin MF, et al. A double-blind controlled trial of bilateral fetal nigral transplan- tation in Parkinson's disease. Ann Neurol 2003; 54: 403-414.

17. Hagell P, Piccini P, Bjorklund A, Brundin P, Rehncrona S, Widner H, Crabb L, Pavese N, Oertel WH, Quinn N, Brooks DJ, Lindvall O. Dyskinesias following neural transplantation in Parkinson's disease. Nat Neurosci 2002; 5 (7): 627-628.

18. Juengst E, Fossel M. The ethics of embryonic stem cells-now and forever, cells without end. JAMA 2000; 283 (31): 3180-3184.

19. Evans MJ, Kaufman MH. Establishment in culture of pluripotential cells from mouse embryos. Nature 1981; 292(5819): 154-6.

20. Hynes M, Rosenthal A. Embryonic stem cells go dopaminergic. Neuron 2000; 28 (1): 11-14.

21. Amit M, Carpenter MK, Inokuma MS, Chiu CP, Harris CP, Waknitz MA, Itskovitz-Eldor J, Thomson JA. Clonally derived human embryonic stem cell lines maintain pluripotency and proliferative potential for prolonged periods of culture. Dev Biol 2000; 227 (2): 271-278.

22. Bjorklund LM, Sanchez-Pernaute R, Chung S, Andersson T, Chen IY, McNaught KS, et al. Embryonic stem cells develop into functional dopaminergic neurons after transplantation in a Parkinson rat model. Proc Natl Acad Sci 2002; 99 (4): 2344-2349.

23. Li JY, Christopherson NS, Hall V, Soulet D, Brundin P. Critical issues of clinical human embryonic stem cell therapy for brain repair. Trends Neurosci 2008; 31: 146-153.

24. Lee SH, Lumelsky N, Studer L, Auerbach JM, McKay RD. Efficient generation of midbrain and hindbrain neurons from mouse embryonic stem cells. Nat Biotechnol 2000; 18 (6): 675-679. 
25. Morizane A, Takahashi J, Shinoyama M, Ideguchi M, Takagi Y, Fukuda H, Koyanagi M, Sasai Y, Hashimoto N. Generation of graftable dopaminergic neuron progenitors from mouse ES cells by a combination of coculture and neurosphere methods. J Neurosci Res 2006; 83 (6): 1015-1027.

26. Fathi F, Mowla SJ, Movahedin M. Transplantation of retinoic acid treated murine embryonic stem cells and behavioural deficit in Parkinsonian rats. Indian J Med Research 2007; 131: 536544.

27. Sánchez-Pernaute R, Studer L, Bankiewicz KS, Major EO, McKay RD. In vitro generation and transplantation of precursor-derived human dopamine neurons. J Neurosci Res 2001; 65 (4): 284288.

28. Schulz TC, Palmarini GM, Noggle SA, Weiler DA, Mitalipova MM, Condie BG. Directed neuronal differentiation of human embryonic stem cells. BMC Neurosci 2003; 4 (27).

29. Brederlau A, Correia AS, Anisimov SV, Elmi M, Paul G, Roybon L, Morizane A, Bergquist F, Riebe I, Nannmark U, Carta M, Hanse E, Takahashi J, Sasai Y, Funa K, Brundin P, Eriksson PS, Li JY. Transplantation of human embryonic stem cell-derived cells to a rat model of Parkinson's disease: effect of in vitro differentiation on graft survival and teratoma formation. Stem Cells. 2006; 24 (6): 1433-1440.

30. Kawasaki H, Mizuseki K, Nishikawa S, Kaneko S, Kuwana Y, Nakanishi S, Nishikawa SI, Sasai $\mathrm{Y}$. Induction of midbrain dopaminergic neurons from ES cells by stromal cell-derived inducing activity. Neuron 2000; 28 (1): 31-40.

31. Kim JH, Auerbach JM, Rodríguez-Gómez JA, Velasco I, Gavin D, Lumelsky N, Lee SH, Nguyen J, Sánchez-Pernaute R, Bankiewicz K, McKay R. Dopamine neurons derived from embryonic stem cells function in an animal model of Parkinson's disease. Nature 2002; 418 (6893): 50-56.

32. Roy NS, Cleren C, Singh SK, Yang L, Beal MF, Goldman SA. Functional engraftment of human ES cell-derived dopaminergic neurons enriched by coculture with telomerase-immortalized midbrain astrocytes. Nat Med 2006; 12 (11): 1259-68.

33. Yang D, Zhang ZJ, Oldenburg M, Ayala M, Zhang SC. Human embryonic stem cell-derived dopaminergic neurons reverse functional deficit in parkinsonian rats. Stem Cells 2008; 26 (1): 55 63.

34. Thinyane K, Baier PC, Schindehutte J, Mansouri A, Paulus W, Trenkwalder C, Flugge G, Fuchs E. Fate of pre-differentiated mouse embryonic stem cells transplanted in unilaterally 6hydroxydopamine lesioned rats: Histological characterization of the grafted cells. Brain Res 2005; 1045 (1-2): 80-87.

35. Chung S, Sonntag KC, Andersson T, Bjorklund LM, Park JJ, Kim DW, Kang UJ, Isacson O, Kim KS. Genetic engineering of mouse embryonic stem cells by Nurr1 enhances differentiation and maturation into dopaminergic neurons. Eur J Neurosci 2002; 16 (10): 1829-1838.

36. Park $\mathrm{CH}$, Lee SH. Efficient generation of dopamine neurons from human embryonic stem cells. Methods Mol Biol 2007; 407: 311-322.

37. Cho MS, Lee YE, Kim JY, Chung S, Cho YH, Kim DS, Kang SM, Lee H, Kim MH, Kim JH, Leem JW, Oh SK, Choi YM, Hwang DY, Chang JW, Kim DW. Highly efficient and large-scale generation of functional dopamine neurons from human embryonic stem cells. Proc Natl Acad Sci 2008; 105 (9): 3392-3397. 
38. Koch P, Opitz T, Steinbeck JA, Ladewig J, Brüstle O. A rosette-type, self-renewing human ES cell-derived neural stem cell with potential for in vitro instruction and synaptic integration. Proc Natl Acad Sci 2009; 106 (9): 3225-3230.

39. Ravindran G, Ramnath RL, Rao HS, Chandra V. One year survival and significant reversal of motor deficits in parkinsonian rats transplanted with hESC derived dopaminergic neurons. Biochem Biophys Res Commun 2008; 373(2): 258-264.

40. Altman J, Das GD. Autoradiographic and histological evidence of postnatal hippocampal neurogenesis in rats. J Comp Neurol 1965; 124: 319-335.

41. Gage FH. Mammalian neural stem cells. Science 2000; 287: 1433-1438.

42. Potter ED, Ling ZD, Carvey PM. Cytokine-induced conversion of mesencephalic- derived progenitor cells into dopamine neurons. Cell Tissue Res 1999; 296 (2): 235-46.

43. O'Keeffe F, Scott SA, Tyers P, O'Keeffe GW, Dalley JW, Zufferey R, Caldwell MA. Induction of A9 dopaminergic neurons from neural stem cells improves motor function in an animal model of Parkinson's disease. Brain 2008; 131: 630-641.

44. Feng ZQ, Ji M, Li YL, Chong gang Y (2009). Grafted neural stem cells migrate to the substantia nigra and improve behaviour in parkinsonian rats. Neurosci letters 2009; 462: 213-218.

45. Hovakimyan M, Haas SJ, Schmitt O, Gerber B, Wree A, Andressen C. Mesencephalic human neural progenitor cells transplanted into the neonatal hemiparkinsonian rat striatum differentiate into neurons and improve motor behaviour. J Anat 2006; 209 (6): 721-732.

46. Redmond DE, Bjugstad KB, Teng YD, Ourednik V, Ourednik J, Wakeman DR, Parsons XH, Gonzalez R, Blanchard BC, Kim SU, Gu Z, Lipton SA, Markakis EA, Roth RH, Elsworth JD, Sledek JR, Sidman RL, Snyder EY. Behavioural improvement in a primate Parkinson's disease model is associated with multiple homeostatic effects of human neural stem cells. PHAS 2007; 104 (29): 12175-12180.

47. Ling ZD, Potter ED, Lipton JW, Carvey PM. Differentiation of mesencephalic progenitor cells into dopaminergic neurons by cytokines. Exp Neurol 1998; 149 (2): 411-423.

48. Svendsen CN, Caldwell MA, Shen J, ter Borg MG, Rosser AE, Tyers P, Karmiol S, Dunnett SB. Long-term survival of human central nervous system progenitor cells transplanted into a rat model of Parkinson's disease. Exp Neurol 1997; 148 (1): 135-146.

49. Storch A, Paul G, Csete M, Boehm BO, Carvey PM, Kupsch A, Schwarz J. Long-term proliferation and dopaminergic differentiation of human mesencephalic neural precursor cells. Exp Neurol 2001; 170 (2): 317-325.

50. Horiguchi S, Takahashi J, Kishi Y, Morizane A, Okamoto Y, Koyanagi M, Tsuji M, Tashiro K, Honjo T, Fujii S, Hashimoto N. Neural precursor cells derived from human embryonic brain retain regional specificity. J Neurosci Res 2004; 75 (6): 817-824.

51. Mimeault M, Batra SK. Concise review: recent advances on the significance of stem cells in tissue regeneration and cancer therapies. Stem Cells 2006; 24: 2319-2345.

52. Gensburger C, Labourdette G, Sensenbrenner M. Brain basic fibroblast growth factor stimulates the proliferation of rat neuronal precursor cells in vitro. FEBS Lett 1987; 217 (1): 1-5.

53. Reynolds BA, Tetzlaff W, Weiss S. A multipotent EGF-responsive striatal embryonic progenitor cell produces neurons and astrocytes. J Neurosci 1992; 12 (11): 4565-4574.

54. Studer L, Tabar V, McKay RD. Transplantation of expanded mesencephalic precursors leads to recovery in parkinsonian rats. Nat Neurosci 1998; 1(4): 290-295. 
55. Jensen P, Pedersen EG, Zimmer J, Widmer HR, Meyer M. Functional effect of FGF2- and FGF8expanded ventral mesencephalic precursor cells in a rat model of Parkinson's disease. Brain Res 2008; 1218: 13-20.

56. Carvey PM, Ling ZD, Sortwell CE, Pitzer MR, McGuire SO, Storch A, Collier TJ. A clonal line of mesencephalic progenitor cells converted to dopamine neurons by hematopoietic cytokines: a source of cells for transplantation in Parkinson's disease. Exp Neurol 2001; 171 (1): 98-108.

57. Liu WG, Wang XJ, Lu GQ, Li B, Wang G, Chen SD. Dopaminergic regeneration by neurturinoverexpressing c17.2 neural stem cells in a rat model of Parkinson's disease. Mol Neurodegener 2007; 2 (19).

58. Burbach JP, Smidt MP. Molecular programming of stem cells into mesodiencephalic dopaminergic neurons. Trends Neurosci 2006; 29 (11): 601-603.

59. Kim JY, Koh HC, Lee JY, Chang MY, Kim YC, Chung HY, Son H, Lee YS, Studer L, McKay R, Lee SH. Dopaminergic neuronal differentiation from rat embryonic neural precursors by Nurr1 overexpression. J neurochem 2003; 85 (6): 1443-1454.

60. Andersson EK, Irvin DK, Ahlsiö J, Parmar M. Ngn2 and Nurr1 act in synergy to induce midbrain dopaminergic neurons from expanded neural stem and progenitor cells. Exp Cell Res 2006; 313 (6): 1172-1180.

61. Ma DK, Bonaguidi MA, Ming GL, Song H. Adult neural stem cells in the mammalian central nervous system. Cell Res 2009; 19: 672-682.

62. D’Ippolito G, Diabira A, Howard GA, Menei P, Roos BA, Schiller PC. Marrow-isolated adult multilineage inducible (MIAMI) cells, a unique population of postnatal young and old human cells with extensive expansion and differentiation potential. J Cell Sci 2004; 117: 2971-2981.

63. Nesti C, Pardini C, Barachini S, D’Alessandro D, Siciliano G, Murri L, Petrini M, Vaglini F. Human dental pulp stem cells protect mouse dopaminergic neurons against MPP+ or rotenone. Brain Res 2010; 1367: 94-102.

64. Murrel W, Wetzig A, Donnellan M, Feron F, Burne T, Meedeniya J, Kesby J, Bianco J, Perry C, Silburn P, Mackay-Sim A. Olfactory Mucosa is a potential source for autologous stem cell therapy for Parkinson's disease. Trans Clin Res 2008; 26: 2183-2192.

65. Buzanska L, Jurga M, Stachowiak EK, Stachowiak MK, Domanska-Janik K. Neural stem-like cell line derived from a nonhematopoietic population of human umbilical cord blood. Stem Cells Dev 2006; 15: 391-406.

66. Shim JW, Park CH, Bae YC, Bae JY, Chung S, Chang MY, Koh HC, Lee HS, Hwang SJ. Lee $\mathrm{KH}$, Lee YS, Choi CY, Lee SH. Generation of functional dopamine neurons from neural precursor cells isolated from the subventricular zone and white matter of the adult rat brain using Nurr1 overexpression. Stem Cells 2007; 25 (5): 1252-1262.

67. Le'vesque MR, Neuman T, Rezak M. Therapeutic microinjection of autologous adult human neural stem cells and differentiated neurons for Parkinson's disease: Five-year post-operative outcome. Open Stem Cell J 2009; 1: 20-29.

68. Jin GZ, Cho SJ, Lee YS, Kim MO, Cho DW, Kong IK. Intrastriatal grafts of mesenchymal stem cells in adult intact rats can elevate tyrosine hydroxylase expression and dopamine levels. Cell Biol Int 2009; 34 (1): 135-140. 
69. Li Y, Chen J, Wang L, Zhang L, Lu M, Chopp M. Intracerebral transplantation of bone marrow stromal cells in a 1-methyl-4-phenyl-1, 2,3, 6-tetrahydropyridine mouse model of Parkinson's disease. Neurosci Lett 2001; 316 (2): 67-70.

70. Bouchez G, Sensebe L, Vourc'h P, Garreau L, Bodard S, Rico A, Guilloteau D, Charbord P, Besnard JC, Chalon S. Partial recovery of dopaminergic pathway after graft of adult mesenchymal stem cells in a rat model of Parkinson's disease. Neurochem Int 2008; 52 (7): 1332-1342.

71. Blandini F, Cova L, Armentero T, Zennaro E, Levandis G, Bossolasco P, Calzarossa C, Mellone M, Giuseppe B, Deliliers GL, Polli E, Nappi G, Silani V. Transplantation of undifferentiated human mesenchymal stem cells protects against 6-hydroxydopamine neurotoxicity in the rat. Cell Transplant 2010; 19: 203-217.

72. Chao YX, He BP, Tay SSW. Mesenchymal stem cell transplantation attenuates blood brain barrier damage and neuroinflammation and protects dopaminergic neurons against MPTP toxicity in the substantia nigra in a model of Parkinson's disease. J Neuroimmunol 2009; 216: 39-50.

73. Kamishina H, Deng J, Oji T, Cheeseman JA, Clemmons RM. Expression of neural markers on bone marrow-derived canine mesenchymal stem cells. Am J Vet Res 2006; 67 (11): 1921-1928.

74. Levy YS, Bahat-Stroomza M, Barzilay R, Burshtein A, Bulvik S, Barhum Y, Panet H, Melamed E, Offen D. Regenerative effect of neural-induced human mesenchymal stromal cells in rat models of Parkinson's disease. Cytotherapy 2008; 10 (4): 340-352.

75. Trzaska KA, Rameshwar P. Dopaminergic neuronal differentiation protocol for human mesenchymal stem cells. Methods Mol Biol 2011; 698: 295-303.

76. Zhang Z, Wang X, Wang S. Isolation and characterization of mesenchymal stem cells derived from bone marrow of patients with Parkinson's disease. In Vitro Cell Dev Biol Anim 2008; 44 (56): 169-177.

77. Venkataramana NK, Kumar SK, Balaraju S, Radhakrishnan RC, Bansal A, Dixit A, Rao DK, Das M, Jan M, Gupta PK, Totey SM. Open-labeled study of unilateral autologous bone-marrowderived mesenchymal stem cell transplantation in Parkinson's disease. Transl Res 2010; 155 (2): 62-70.

78. Watts RL, Raiser CD, Stover NP, Cornfeldt ML, Schweikert AW, Allen RC, Subramanian T, Doudet D, Honey CR, Bakay RA. Stereotaxic intrastriatal implantation of human retinal pigment epithelial (hRPE) cells attached to gelatin microcarriers: a potential new cell therapy for Parkinson's disease. J Neural Transm Suppl 2003; (65): 215-227.

79. Cepeda IL, Flores J, Cornfeldt ML, O'Kusky JR, Doudet DJ. Human retinal pigment epithelial cell implants ameliorate motor deficits in two rat models of Parkinson disease. J Neuropathol Exp Neurol 2007; 66 (7): 576-584.

80. Ming M, Li X, Fan X, Yang D, Li L, Chen S, Gu Q, Le W. Retinal pigment epithelial cells secrete neurotrophic factors and synthesize dopamine: possible contribution to therapeutic effects of RPE cell transplantation in Parkinson's disease. J Transl Med 2009; 7: 53.

81. Gross RE, Watts RL, Hauser RA, Bakay RA, Reichmann H, von Kummer R, Ondo WG, Reissig E, Eisner W, Steiner-Schulze H, Siedentop H, Fichte K, Hong W, Cornfeldt M, Beebe K, Sandbrink R; the Spheramine Investigational Group. Intrastriatal transplantation of microcarrierbound human retinal pigment epithelial cells versus sham surgery in patients with advanced Parkinson's disease: a double-blind, randomised, controlled trial. Lancet Neurol 2011; 10 (6): 509-519. 
82. Kiskinis E, Eggan K. Progress toward the clinical application of patient-specific pluripotent stem cells. J Clin Invest 2010; 120 (1): 51-59.

83. Takahashi K, Yamanaka S. Induction of pluripotent stem cells from mouse embryonic and adult fibroblast cultures by defined factors. Cell 2006; 126 (4): 663-676.

84. Takahashi K, Tanabe K, Ohnuki M, Narita M, Ichisaka T, Tomoda K, Yamanaka S. Induction of pluripotent stem cells from adult human fibroblasts by defined factors. Cell 2007; 131 (5): 861872.

85. Yu J, Vodyanik MA, Smuga-Otto K, Antosiewicz-Bourget J, Frane JL, Tian S, Nie J, Jonsdottir GA, Ruotti V, Stewart R, Slukvin II, Thomson JA. Induced pluripotent stem cell lines derived from human somatic cells. Science 2007; 318 (5858): 1917-1920.

86. Wernig M, Meissner A, Foreman R, Brambrink T, Ku M, Hochedlinger K, Bernstein BE, Jaenisch R. In vitro programming of fibroblasts into a pluripotent ES-cell like state. Nature 2007; 448: 318-324.

87. Swistowski A, Peng J, Liu Q, Mali P, Rao MS, Cheng L, Zeng X. Efficient generation of functional dopaminergic neurons from human induced pluripotent stem cells under defined conditions. Stem Cells 2010; 28 (10): 1893-1904.

88. Hargus G, Cooper O, Deleidi M, Levy A, Lee K, Marlow E, Yow A, Soldner F, Hockemeyer D, Hallett PJ, Osborn T, Jaenisch R, Isacson O. Differentiated Parkinson patient derived induced pluripotent stem cells grow in the adult rodent brain and reduce motor asymmetry in Parkinsonian rats. PNAS 2010; 107 (36): 15921-15926.

89. Cai J, Yang M, Poremsky E, Kidd S, Schneider JS, Lavovitti L. Dopaminergic neurons derived from human induced pluripotent stem cells survive and integrate into 6-OHDA-lesioned rats. Proc Natl Acad Sci 2010; 19 (7): 1017-1023.

90. Park IH, Arora N, Huo H, Maherali N, Ahfeldt T, Shimamura A, Lensch MW, Cowan C, Hochedlinger K, Daley GQ. Disease-specific induced pluripotent stem cells. Cell 2008; 134 (5): 877-886.

91. Soldner F, Hockemeyer D, Beard C, Gao Q, Bell GW, Cook EG, Hargus G, Blak A, Cooper O, Mitalipova M, Isacson O, Jaenisch R. Parkinson's disease patient-derived induced pluripotent stem cells free of viral reprogramming factors. Cell 2009; 136 (5): 964-977.

92. Kordower JH, Chu Y, Hauser RA, Freeman TB, Olanow CW. Lewy body-like pathology in longterm embryonic nigral trans- plants in Parkinson's disease. Nat Med 2008; 14: 504-506.

93. Li JY, Englund E, Holton JL et al. Lewy bodies in grafted neurons in subjects with Parkinson's disease suggest host-to-graft disease propagation. Nat Med 2008; 14: 501-503.

94. Okita K, Ichisaka T, Yamanaka S. Generation of germline-competent induced pluripotent stem cells. Nature 2007; 448 (7151): 313-317.

95. Krizhanovsky V, Lowe SW. Stem cells: the promises and perils of p53. Nature 2009; 460; $1085-$ 1086.

96. Vierbuchen T, Ostermeier A, Pang ZP, Kokubu Y, Südhof TC, Wernig M. Direct conversion of fibroblasts to functional neurons by defined factors. Nature 2010; 463 (7284): 1035-1041.

97. Hermann A, Storch A. Endogenous regeneration in Parkinson's disease: do we need orthotopic dopaminergic neurogenesis? Stem cells 2008; 26 (11): 2749-52. 
98. Gaillard A, Decressac M, Frappé I, Fernagut PO, Prestoz L, Besnard S, Jaber M. Anatomical and functional reconstruction of the nigrostriatal pathway by intranigral transplants. Neurobiol Dis 2009; 35 (3): 477-488.

99. Zhou FC, Chiang YH, Wang Y. Constructing a new nigrostriatal pathway in the Parkinsonian model with bridged neural transplantation in substantia nigra. J Neurosci 1996; 16 (21): 69656974.

100. Chiang Y, Morales M, Zhou FC, Borlongan C, Hoffer BJ, Wang Y. Fetal intra-nigral ventral mesencephalon and kidney tissue bridge transplantation restores the nigrostriatal dopamine pathway in hemi-parkinsonian rats. Brain Res 2001; 889 (1-2): 200-207.

101. Drury JL, Mooney DJ. Hydrogels for tissue engineering: scaffold design variables and applications. Biomaterials 2003; 24 (24): 4337-4351.

102. Discher DE, Janmey P, Wang YL. Tissue cells feel and respond to the stiffness of their substrate. Science 2005; 310 (5751): 1139-1143.

103. Pridgen EM, Langer R, Farokhzad OC. Biodegradable, polymeric nanoparticle delivery systems for cancer therapy. Nanomedicine 2007; 2 (5): 669-680.

104. Fischbach C, Mooney DJ. Polymers for pro -and anti angiogenic therapy. Biomaterials 2007; 28 (12): 2069-2076.

105. Doetsch F. The glial identity of neural stem cells. Nat Neurosci 2003; 6: 1127-1134.

106. Ming GL, Song H. Adult neurogenesis in the mammalian central nervous system. Annu Rev Neurosci 2005; 28: 223-250.

107. Zhao M, Momma S, Delfani K et al. Evidence for neurogenesis in the adult mammalian substantia nigra. Proc Natl Acad Sci 2003; 100: 7925-7930.

108. Nunes MC, Roy NS, Keyoung HM et al. Identification and isolation of multipotential neural progenitor cells from the subcortical white matter of the adult human brain. Nat Med 2003; 9: 439-447.

109. Eriksson PS, Perfilieva E, Bjork-Eriksson T, Alborn AM, Nordborg C, Peterson DA, et al. Neurogenesis in the adult human hippocampus. Nat Med 1998; 4 (11): 1313-1317.

110. Geraerts M, Krylyshkina O, Debyser Z, Baekelandt V. Concise review: therapeutic strategies for Parkinson disease based on the modulation of adult neurogenesis. Stem Cells 2007; 25 (2): 263 270.

111. Fallon J, Reid S, Kinyamu R et al. In vivo induction of massive proliferation, directed migration, and differentiation of neural cells in the adult mammalian brain. Proc Natl Acad Sci 2000; 97: 14686-14691.

112. Martens DJ, Seaberg RM, van der Kooy D. In vivo infusions of exogenous growth factors into the fourth ventricle of the adult mouse brain increase the proliferation of neural progenitors around the fourth ventricle and the central canal of the spinal cord. Eur J Neurosci 2002; 16 (6): 1045-1057.

113. Jin K, Sun Y, Xie L, Peel A, Mao XO, Batteur S, Greenberg DA. Directed migration of neuronal precursors into the ischemic cerebral cortex and striatum. Mol Cell Neurosci 2003; 24 (1): 171189.

114. Mohapel P, Frielingsdorf H, Haggblad J et al. Platelet-derived growth factor (PDGF-BB) and brain-derived neurotrophic factor (BDNF) induce striatal neurogenesis in adult rats with 6hydroxydopamine lesions. Neurosci 2005; 132: 767-776. 
115. Benraiss A, Chmielnicki E, Lerner K et al. Adenoviral brain-derived neurotrophic factor induces both neostriatal and olfactory neuronal recruitment from endogenous progenitor cells in the adult forebrain. J Neurosci 2001; 21: 6718-6731.

116. Cooper O, Isacson O. Intrastriatal transforming growth factor alpha delivery to a model of Parkinson's disease induces proliferation and migration of endogenous adult neural progenitor cells without differentiation into dopaminergic neurons. J Neurosci 2004; 24: 8924-893.

(C) 2011 by the authors; licensee Insciences Journal.

Open Access article under the terms and conditions of Creative Commons Attribution Non-Commercial License 3.0 Unported. 